\title{
Improving Conservation through Cultivation: Nine Container Substrates Influence Growth of a Rare Cycad, Zamia pumila L.
}

\author{
Vickie Murphy ${ }^{1}$ \\ Montgomery Botanical Center, 11901 Old Cutler Road, Coral Gables, FL \\ 33156; and University of Florida, Fort Lauderdale Research \& Education \\ Center, 3205 College Avenue, Davie, FL 33314
}

\author{
Kimberly Moore ${ }^{2}$ \\ University of Florida, Fort Lauderdale Research \& Education Center, 3205 \\ College Avenue, Davie, FL 33314
}

\author{
M. Patrick Griffith ${ }^{3}$ and Chad Husby ${ }^{4,5}$ \\ Montgomery Botanical Center, 11901 Old Cutler Road, Coral Gables, FL \\ 33156
}

Additional index words. aeration, conservation horticulture, container cultivation, cycads, drainage, inert substrates, particle size distribution, physical properties

\begin{abstract}
Cycads comprise the most threatened major group of plants on earth and many species require horticultural assistance to ensure their survival. Appropriate container substrate properties, especially relatively high air space content, are crucial to successful cultivation of most cycads from seed. Cycad substrates in common use include substantial portions of organic materials that will decompose over time, reducing aeration. At Montgomery Botanical Center, novel inorganic substrates have improved survival and growth of several very rare and challenging Zamia species, suggesting the need for a rigorous evaluation of different inorganic container substrates. Effects of 1) coarse silica sand (6/20 grade); 2) Fafard (a peat/perlite mix); 3) perlite (expanded volcanic glass); 4) pumice (volcanic rock); 5) Turface (calcined clay); 6) Profile (calcined clay); 7) a 50\% sand (6/20): 50\% Profile mix; 8) Permatil (calcined slate); or 9) Axis (calcined diatomaceous earth) on growth of Zamia pumila L. seedlings (grown from seed of Dominican Republic provenance) were evaluated. Growth parameters were measured after 18 months. Sand produced significantly higher total dry weight and leaf area than all other substrates. A combination of at least $18 \%$ air space combined with little coarse material (sand) or with some coarse material combined with enough smaller particles to fill part of the large pores created by coarse material (Fafard) likely contributed to better growth in these compared with the other seven substrates. The other substrates may have been either too coarse, leading to excessively large pores, which are known to inhibit growth in some plants if the pores are much larger than fine root diameters, or too fine (i.e., too low of an air space percentage). The fine roots of Zamia can be less than $1 \mathrm{~mm}$ in diameter, whereas higher proportions of coarse substrate particles over $4 \mathbf{m m}$ in diameter inhibited growth, possibly by creating excessively large pores. In contrast, higher proportions of fine substrate particles of 0.25 to $0.5 \mathrm{~mm}$ were beneficial to growth.
\end{abstract}

Cycads represent one of the earliest seed plant lineages, originating $\approx 300$ million years ago. According to the 2010 International Union for Conservation of Nature (IUCN) Red List, 62\% of the world's cycads are threatened with extinction (IUCN Red List of Threatened Species, 2010). This is a $16 \%$ increase from the $46 \%$ that were considered to be threatened in 1978. Cycads are the most threatened group of plant species on Earth as a result of loss of habitat and overcollection in the wild. The cycad specialist group of IUCN recommends concerted efforts to improve propagation and cultivation of cycads (Donaldson et al., 2003). Although progress has been made in cycad horticulture, cycad conservation depends on successful cultivation of ex situ "off-site" collections (Chavez and Litz, 2007; Dehgan, 1999; Donaldson et al., 2003). This can not only conserve species directly, but also reduce poaching pressure on wild populations by making ex situ-propagated plants available to horticulture (Calonje et al., 2011; Kay et al., 2011). There is a greater than $90 \%$ mortality rate of Zamia seeds in the wild (Tang, 1990), showing that seed can be carefully collected from the wild without adversely affecting natural populations. Seed-propagated cycads can be reintroduced into native habitats to prevent genetic erosion and extinction of wild populations (Walters, 1999).

All Zamia (Zamiaceae) are New World plants, currently comprising 75 species (Calonje et al., 2013). Many Zamia are from Central America, but species can be found in the
Bahamas, Cuba, Colombia, Costa Rica, Mexico, Panama, and Florida. Commercially produced substrates would not necessarily be readily available in these countries. The ability to use whatever inorganic substrates are naturally occurring in each country could greatly benefit conservation efforts. Therefore, it is important to develop a better understanding of which substrates and substrate properties are most conducive to Zamia growth.

Good drainage is crucial to successfully growing cycads (Whitelock, 2002). Drainage of organic substrates can decline over time as decomposition occurs (Bilderback et al., 2005). Decomposition of organic materials depends on the nature of materials and on climatic conditions, being especially rapid in warm conditions required by cycads. Therefore, inorganic materials may prove to be excellent substrates for long-term cycad growth.

Prior work includes research on the effects of inorganic substrates vs. organic substrates on germination and early seedling growth of Z. fairchildiana, Z. cunaria, and $Z$. portoricensis (Calonje et al., 2010). Over a period of 14 months, Turface, silica sand $(6 / 20)$, and one mixed substrate (organic and inorganic components) performed adequately for germination and growth of Zamia species. Furthermore, several other rare Zamia at Montgomery Botanical Center have been observed to grow well in inorganic substrates, and some have proven particularly effective in arresting rot. Some rare Zamia species are extremely difficult to grow and appear to require careful attention to substrate choice. Others such as the $Z$. pumila used in this study are rather easy to grow.

Soilless mixtures such as a 1:1:1 ratio of sharp sand, perlite, and pine bark have been commonly used to grow Zamia plants. Organic mixtures containing peat, pine bark, and/or sphagnum have the disadvantage of decomposing rapidly, resulting in a compressed substrate that inhibits air circulation to roots. Furthermore, most standard growing substrates are more or less hydrophobic in the dry state, making initial wetting and rewetting difficult (Michel, 2009). Rischer (2000) found that plants previously potted in organic substrates and transplanted into inorganic substrates showed no signs of stress, probably because the roots retained enough of the original organic substrate to buffer the roots during the establishment period. Similarly, Turface (Profile Products LLC, Buffalo Grove, IL), an inorganic baked (calcined) clay substrate, has been used in the successful propagation of Cycas micronesica from Guam, Zamia decumbens from Belize, and Caribbean Zamia species (Griffith et al., 2010).

A number of inorganic substrates and substrate components such as perlite, vermiculite, turface, rockwool, and baked clay balls have long been used in the United States and Europe for a wide range of plants and are being increasingly used in Asia (Kang et al., 2004). Turface and Profile (Profile Products LLC), of the same baked clay composition but with different particle sizes, have been used for several species of Cycas, Dioon, 
Encephalartos, Macrozamia, Microcycas, and Zamia. However, the performance of these substrates for cycad growth has had little rigorous evaluation in the literature.

The objective of this study is to compare Z. pumila growth in eight little-used inorganic substrates and one mainstream organic nursery substrate. The emphasis on inorganic substrates is partly the result of field research in the native habit of $Z$. pumila documenting plants growing in limestone, a hard rock formed by marine coralline deposit, and sand near the coastal area (Zanoni, 1982). Zamia pumila, a species native to the Dominican Republic, is a typical representative of the cycads of the Caribbean basin, which includes the most commonly cultivated Zamiaceae in North America, Z. furfuracea L.f. ex Aiton of Mexico and Z. integrifolia L.f. ex Aiton of Florida.

The name Z. pumila was long applied to the Zamia species native to Florida but is now used for plants originating from the Dominican Republic and some plants from other Caribbean islands (Osborne et al., 2012). However, nursery growers of the Florida native $Z$. integrifolia still commonly use the name $Z$. pumila.

\section{Materials and Methods}

Approximately 1600 garden-origin $Z$. pumila seeds were collected from several mother plants in the collections of the Jardin Botanico Nacional Dr. Rafael Ma. Moscoso (Dominican Republic) on 8 Feb. 2010 and shipped to Montgomery Botanical Center (MBC). Although the species used in this study, Z. pumila, is near threatened in the wild, it is not uncommon in cultivation in the Dominican Republic. This abundance of garden-origin seed was donated to $\mathrm{MBC}$ and allowed the plants in this experiment to be harvested for dry weight measurements, which are more precise and direct than the non-destructive methods used in a previous study with rare wild-collected Zamia (Calonje et al., 2010). Thus, no wild-origin plant

Received for publication 14 Mar. 2013. Accepted for publication 15 July 2013 .

We thank Montgomery Botanical Center for funding this project. We also thank Francisco Jimenez, Alberto Veloz, and Michael Calonje for collecting the Zamia pumila seed used in the experiment. We thank the following people for helping with data collection and horticultural care: Albert Diaz, Xavier Gratacos, Trish Hicks, Lynn Leverett, Margaret Martin, Lane Park, Cecelia Thornton, and Bill Walker.

Mention of a trademark, proprietary product, or vendor does not constitute a guarantee or warranty of the product by the Montgomery Botanical Center and does not imply its approval to the exclusion of other products or vendors that also may be suitable.

${ }^{1}$ Nursery Curator.

${ }^{2}$ Professor.

${ }^{3}$ Executive Director.

${ }^{4}$ Collections Manager and Botanist.

${ }^{5}$ To whom reprint requests should be addressed; e-mailchad@montgomerybotanical.org. material was harvested to make this study possible.

Seeds were sown in Fafard Super Fine Germinating Mix (Conrad Fafard, Inc., Agawam, MA) on 20 July 2010 in 0.946-L sealed in plastic bags and placed in a dark closet for germination at ambient temperatures ranging from 21 to $27{ }^{\circ} \mathrm{C}$. Seeds were checked weekly for signs of germination.

By 1 Sept. 2010, 905 seeds had germinated. Seedlings were transplanted into Deepot D27L (Stuewe \& Sons, Inc., Tangent, OR) 7-inch tubes with a volume of $444 \mathrm{~mL}$ filled with Profile (Profile Products LLC), a fine porous ceramic material. POLY-FIL, a polyester fiber (Fairfield Processing, Danbury, CT), was placed in the bottom of the tube to hold Profile in the pot. D27L tubes were placed into Nova-25 trays (Stuewe \& Sons, Inc.) for support.

One hundred thirty-five seedlings (45 seedlings from each of three mother plants) were randomly selected for the experiment. Five individual seedlings from each mother plant were assigned a treatment to provide a total of 15 seedlings per treatment spread evenly across the three half-sibling groups corresponding to the mother plants. Thus, differences among mother plants were controlled by the assignment of treatments across the half-sibling groups. Seedlings were transplanted into $3.785-\mathrm{L}(17.1 \mathrm{~cm} \mathrm{~h} \times 16.5 \mathrm{~cm} \mathrm{w})$ Poly-Tainer PTC700 (Nursery Supplies, Chambersburg, PA) containers filled with 1) sand: coarse silica sand (6/20 grade; FL Silica Sand Company, Fort Lauderdale, FL); 2) perlite: heat-expanded volcanic glass (W.R. Grace \& Co., Cambridge, MA); 3) pumice: lightweight volcanic rock (Hess Pumice Products, Malad City, ID); 4) Turface: calcined montmorillinite clay (Profile Products LLC); 5) Profile: calcined montmorillinite clay (Profile Products LLC); 6) 50\% sand $(6 / 20) / 50 \%$ Profile $(1: 1)$; 7) PermaTill: calcined slate (Carolina Stalite Company, Salisbury, NC); 8) Axis: calcined diatomaceous earth (EnviroTech Soil Solutions, Oregon City, OR); or 9) Fafard potting mix \#2: sphagnum peatmoss $(70 \%)$, perlite $(20 \%)$ vermiculite $(10 \%)$, starter nutrients, wetting agent, and dolomitic limestone (Conrad Fafard Inc.). One pot was placed within another to prevent leakage of the substrate. At transplanting, $35 \mathrm{~g}$ of Nutricote fertilizer $18 \mathrm{~N}-$ 2.62P-6.64K slow-release 360 (Florikan E.S.A., Sarasota, FL) was incorporated into the top 1 inch of the substrate. Plants were again fertilized at the same rate after 1 year on 1 Oct. 2011.

Plants were placed on a raised bench in a glass greenhouse. The experiment was arranged as a randomized complete-block design to control for environmental gradients from the side to the center of the greenhouse (blocks were parallel to the long axis of the greenhouse). Temperatures ranged from 15.5 to $32^{\circ} \mathrm{C}$. Plants were hand-watered three times a week to the point of saturation using municipal water.

Leaf and leaflet counts were recorded periodically during the experiment. On 1 May 2012 all plants were evaluated visually for growth and overall appearance using a rating scale of 0 to 5 (Fig. 1).

On 1 May 2012, plants were harvested for dry weight and leaf area measurements. Leaves were separated from the rest of the plant. Leaflets were separated from the rachis and used for leaf area analysis with a LI-3000 portable area meter console and head (LI-COR, Inc., Lincoln, NE).

Plants were removed from their pots and the substrate was rinsed off with gentle water pressure. Stem diameter was measured using a digital caliper (Fred V. Fowler Co., Newton, MA). The stem was separated from the root system and dried separately. Leaflets, petioles, stems, and roots were dried separately at $63{ }^{\circ} \mathrm{C}$ for $7 \mathrm{~d}$ for dry weight determination.

Substrate particle size distributions of substrates were measured using a Hubbard Scientific \#548 six screen sieve set (Hubbard Scientific Inc., Chippawa Falls, WI). Sieve retention percentages were determined by weight. Air space, water-holding capacity, and total porosity were measured on a volume basis. The containers used for testing were

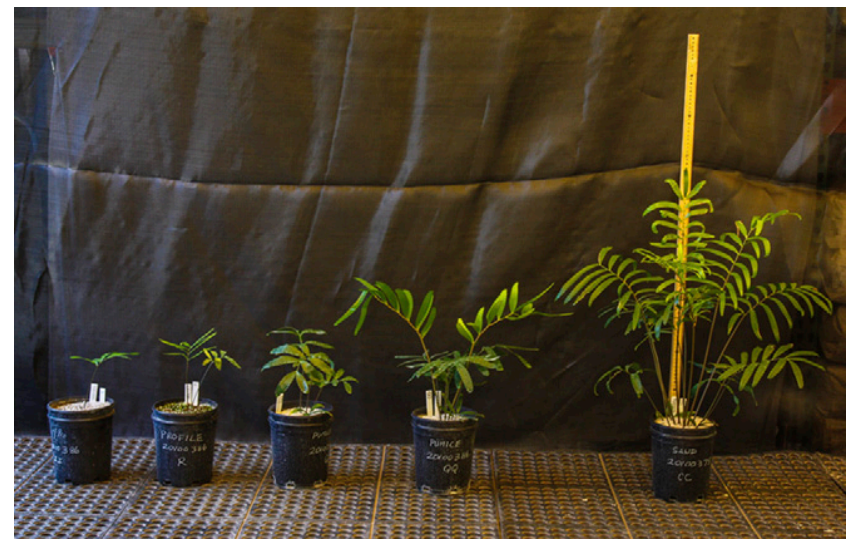

Fig. 1. Zamia pumila quality ratings after 18 months of growth in nine different substrates under identical conditions. Living plants with no leaves were rated 0 (not shown). Plants with at least one leaf were rated as followed (from left to right): poor-quality plants with one leaf were rated 1; fair-quality plants with two leaves were rated 2; good-quality plants were rated 3 if they had three leaves, 4 if they had four to five leaves. Excellent quality plants with the most leaves (greater than 5) were rated 5. A 1-m ruler is shown behind the plant on the far right. 
3.785-L Poly-Tainer PTC700 (Nursery Supplies). Container volume was measured and it was then filled with oven-dried substrate and weighed to determine dry weight. Water was added until all pore spaces were filled. Water was then drained off and measured to determine water holding capacity, air space, and total porosity $(n=3)$.

Cation exchange capacity (meq/100 g); electrical conductivity (EC; mmhos $\cdot \mathrm{cm}^{-1}$ ); $\mathrm{pH}$; and nitrogen $\left(\mathrm{mg} \cdot \mathrm{L}^{-1}\right)$, available phosphorus $\left(\mathrm{mg} \cdot \mathrm{L}^{-1}\right)$, potassium $\left(\mathrm{mg} \cdot \mathrm{L}^{-1}\right)$, magnesium $\left(\mathrm{mg} \cdot \mathrm{L}^{-1}\right)$, and calcium $\left(\mathrm{mg} \cdot \mathrm{L}^{-1}\right)$ were determined by A\&L Southern Agricultural Laboratories, LLC (Deerfield Beach, FL) on one sample of each substrate.

All variables except for quality rating were analyzed by a randomized completeblock analysis of variance using JMP 9.0.2. (SAS Institute, Inc., Cary, NC). Subsequently a post hoc multiple comparisons test, Tukey's honestly significant difference, was used to perform pairwise comparisons between treatments. The categorical quality rating variable was analyzed by contingency table analysis, testing for non-homogeneity using a Pearson $\chi^{2}$ goodness-of-fit test. In addition, multiple regression models were developed using forward selection based on the Akaike Information Criterion to determine effects of soil physical properties on the growth components. As a result of non-homogeneity of residuals, natural logarithm transformations were used on the growth measurements.

\section{Results}

Zamia growth. Leaf area, leaf number, leaflet number, and stem diameter were highest in containers filled with coarse silica sand and lowest in containers filled with Axis and Permatil (Table 1; Fig. 2). Plants grown in sand had the highest average leaf area $\left(1886.81 \mathrm{~cm}^{2}\right)$, whereas plants grown in Axis produced the least leaf area $\left(13.88 \mathrm{~cm}^{2}\right)$. Plants grown in sand produced 25 times as many leaves as did those in Axis and had the highest mean leaflet count (111). Plants in sand produced the largest stem diameter (46.5 mm), whereas those in Permatil produced the lowest stem diameter $(16.4 \mathrm{~mm})$. All plants grown in sand were given the highest quality rating of 5 (Table 1; Figs. 1 and 2).

Leaf dry weight, shoot dry weight, root dry weight, and total plant dry weight also were highest for plants grown in sand (Table 2). Plants grown in Fafard, perlite, and pumice had higher leaf, root, and total dry weight compared with plants grown in Turface, Profile, sand/Profile, Permatil, or Axis (Table 2). Plants grown in sand/Profile, Axis, and Permatil had the lowest stem, leaf, root, and total dry weights (Table 2).

Quality rating showed significant nonhomogeneity among treatments (Pearson $\chi^{2}$ $P<0.0001)$. Pairwise comparisons were not performed.

Physical properties of substrates. Sand had the lowest initial $\mathrm{pH}$ (4.4, based on one sample) and a low initial EC (Table 3). The $\mathrm{pH}$ of pumice was the highest, whereas perlite
Table 1. Final fresh Zamia pumila tissue growth measurements of plants grown in nine substrates for 18 months. ${ }^{\mathrm{z}}$

\begin{tabular}{lccccc}
\hline Substrate & Leaf area $\left(\mathrm{cm}^{2}\right)$ & Leaf no. & Leaflet no. & Stem diam $(\mathrm{mm})$ & Quality rating \\
\hline Sand $(6 / 20)$ & $1886.81 \mathrm{a}$ & $10.7 \mathrm{a}$ & $111.0 \mathrm{a}$ & $46.54 \mathrm{a}$ & 5.0 \\
Fafard & $1543.67 \mathrm{~b}$ & $9.6 \mathrm{ab}$ & $97.2 \mathrm{a}$ & $38.45 \mathrm{~b}$ & 4.7 \\
Perlite & $1069.39 \mathrm{c}$ & $8.1 \mathrm{~b}$ & $64.5 \mathrm{~b}$ & $39.31 \mathrm{ab}$ & 4.6 \\
Pumice & $729.77 \mathrm{~d}$ & $6.0 \mathrm{c}$ & $44.5 \mathrm{~b}$ & $37.23 \mathrm{~b}$ & 3.7 \\
Turface & $202.25 \mathrm{e}$ & $3.1 \mathrm{~d}$ & $18.2 \mathrm{c}$ & $27.32 \mathrm{c}$ & 2.3 \\
Profile & $163.34 \mathrm{e}$ & $3.1 \mathrm{~d}$ & $19.2 \mathrm{c}$ & $26.60 \mathrm{~cd}$ & 2.2 \\
Sand/Pro & $130.87 \mathrm{e}$ & $2.9 \mathrm{~d}$ & $15.9 \mathrm{c}$ & $24.85 \mathrm{~cd}$ & 2.1 \\
Permatil & $85.17 \mathrm{e}$ & $1.7 \mathrm{de}$ & $8.9 \mathrm{c}$ & $16.40 \mathrm{e}$ & 1.3 \\
Axis & $13.88 \mathrm{e}$ & $0.7 \mathrm{de}$ & $3.0 \mathrm{c}$ & $19.35 \mathrm{de}$ & 0.7 \\
\hline
\end{tabular}

${ }^{2}$ Different letters beside the values denote statistically significant differences (Tukey's honestly significant difference). For all analyses of variance, the $P$ values for the model F ratio were $<0.0001$. A contingency table analysis was carried out for quality rating and showed significant non-homogeneity (Pearson $\chi^{2}$ $P$ value $<0.0001$ ), but no pairwise comparisons were made. $\mathrm{N}=15$ per treatment.

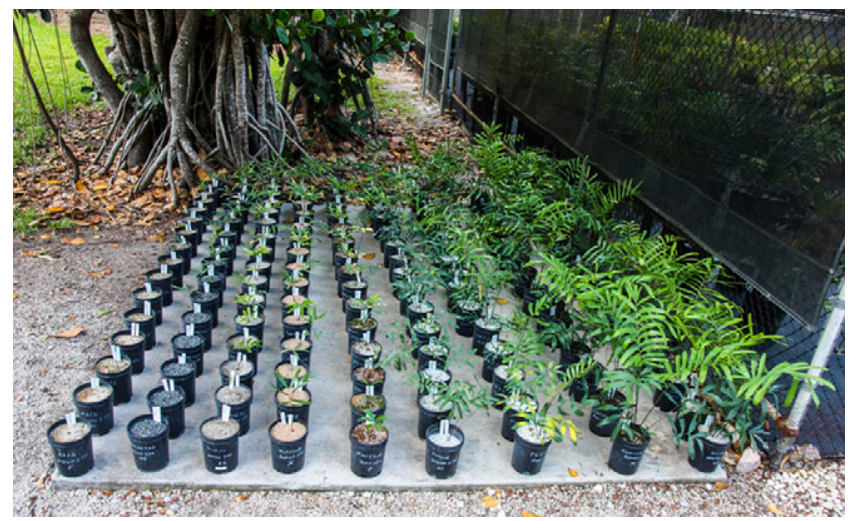

Fig. 2. Zamia pumila growth after 18 months in nine different substrates under identical conditions. At the end of the experiment, before dry weight measurements, plants were arranged in rows according to substrate with the substrates from those producing the least growth (on the left) to those producing the most growth (on the right). From right to left: 1) coarse silica sand (6/20 grade); 2) Fafard (a peat/perlite mix); 3) perlite; 4) pumice; 5) Profile (fine calcined clay); 6) Turface (coarse calcined clay); 7) a $50 \%$ sand (6/20):50\% Profile mix; 8) Permatil (calcined slate); or 9) Axis (calcined diatomaceous earth). This does not show the randomized complete-block design of the experiment.

Table 2. Final Zamia pumila dry tissue growth measurements of plants grown in nine substrates for 18 months. $^{z}$

\begin{tabular}{lcccc}
\hline Substrate & Leaf dry wt $(\mathrm{g})$ & Stem dry wt $(\mathrm{g})$ & Root dry wt $(\mathrm{g})$ & Total dry wt $(\mathrm{g})$ \\
\hline Sand $(6 / 20)$ & $21.95 \mathrm{a}$ & $22.47 \mathrm{a}$ & $10.00 \mathrm{a}$ & $54.41 \mathrm{a}$ \\
Fafard & $19.88 \mathrm{a}$ & $12.21 \mathrm{~b}$ & $6.77 \mathrm{~b}$ & $38.86 \mathrm{~b}$ \\
Perlite & $12.04 \mathrm{~b}$ & $12.47 \mathrm{~b}$ & $6.95 \mathrm{~b}$ & $31.47 \mathrm{bc}$ \\
Pumice & $7.82 \mathrm{~b}$ & $9.19 \mathrm{bc}$ & $6.74 \mathrm{~b}$ & $23.75 \mathrm{c}$ \\
Turface & $2.07 \mathrm{c}$ & $4.62 \mathrm{~cd}$ & $2.25 \mathrm{c}$ & $8.93 \mathrm{~d}$ \\
Profile & $1.57 \mathrm{c}$ & $4.37 \mathrm{~cd}$ & $2.10 \mathrm{c}$ & $8.046 \mathrm{~d}$ \\
Sand/Pro & $1.33 \mathrm{c}$ & $4.14 \mathrm{~d}$ & $1.94 \mathrm{c}$ & $7.40 \mathrm{~d}$ \\
Permatil & $0.79 \mathrm{c}$ & $1.84 \mathrm{~d}$ & $1.17 \mathrm{c}$ & $3.80 \mathrm{~d}$ \\
Axis & $0.12 \mathrm{c}$ & $1.38 \mathrm{~d}$ & $0.61 \mathrm{c}$ & $2.11 \mathrm{~d}$ \\
\hline
\end{tabular}

${ }^{2}$ Different letters beside the values denote statistically significant differences (Tukey's honestly significant difference) based on natural logarithm-transformed data to homogenize residual variances (although the means in the table are untransformed). For all analyses of variance, the $P$ values for the model F ratio were $<0.0001$.

Table 3. Initial chemical properties of the nine growing substrates used to grow Zamia pumila for 18 months. $^{\text {z }}$

\begin{tabular}{lcccccccc}
\hline Substrate & $\begin{array}{c}\mathrm{N} \\
\left(\mathrm{mg} \cdot \mathrm{L}^{-1}\right)\end{array}$ & $\begin{array}{c}\mathrm{P} 1 \\
\left(\mathrm{mg} \cdot \mathrm{L}^{-1}\right)\end{array}$ & $\begin{array}{c}\mathrm{K} \\
\left(\mathrm{mg} \cdot \mathrm{L}^{-1}\right)\end{array}$ & $\begin{array}{c}\mathrm{Mg} \\
\left(\mathrm{mg} \cdot \mathrm{L}^{-1}\right)\end{array}$ & $\begin{array}{c}\mathrm{Ca} \\
\left(\mathrm{mg} \cdot \mathrm{L}^{-1}\right)\end{array}$ & $\begin{array}{c}\mathrm{CEC} \\
(\mathrm{meq} / 100 \mathrm{~g})\end{array}$ & $\mathrm{pH}$ & $\begin{array}{c}\mathrm{EC} \\
\left(\mathrm{mmhos} \cdot \mathrm{cm}^{-1}\right)\end{array}$ \\
\hline Sand $(6 / 20)$ & 56 & 1 & 7 & 1 & 34 & 1.8 & 4.4 & 0.21 \\
Fafard & 94 & 4 & 132 & 159 & 346 & 4.6 & 5.5 & 0.39 \\
Perlite & 4 & 1 & 11 & 1 & 1 & 0.1 & 6.4 & 0.03 \\
Pumice & 8 & 1 & 35 & 1 & 207 & 1.1 & 7.3 & 0.12 \\
Turface & 21 & 1 & 316 & 24 & 104 & 1.7 & 6.1 & 0.14 \\
Profile & 78 & 1 & 367 & 40 & 120 & 2.7 & 5.4 & 0.28 \\
Sand/Pro & 62 & 1 & 254 & 60 & 273 & 3.5 & 5.4 & 0.44 \\
Permatil & 7 & 1 & 21 & 1 & 54 & 0.5 & 5.8 & 0.16 \\
Axis & 0 & 1 & 79 & 14 & 102 & 0.8 & 6.9 & 0.04 \\
\hline
\end{tabular}

${ }^{\mathrm{z}}$ One sample of each substrate was analyzed before Nutricote was added.

$\mathrm{N}$, nitrogen; $\mathrm{P} 1$, available phosphorus; $\mathrm{K}$, potassium; $\mathrm{Mg}$, magnesium; $\mathrm{Ca}$, calcium; $\mathrm{CEC}$, cation exchange capacity; EC, electrical conductivity. 
had the lowest EC. Although Permatil had the lowest water-holding capacity, it had the highest air-filled space and this might have been too dry for optimum Zamia growth (Table 4). Fafard had higher air space percentage than sand, but the relative amount of air space to total pore space was higher for sand.

All the substrates had the majority of particles in size classes $0.5 \mathrm{~mm}$ or greater with only Fafard and Profile having a substantial proportion of smaller sized particles (Table 5). Permatil was the only substrate with particle size significantly larger than $4 \mathrm{~mm}(98 \%)$. Perlite (79\%), pumice $(90 \%)$, and Turface $(67 \%)$ had the majority of

Table 4. Initial physical properties of nine growing substrates used to grow Zamia pumila for 18 months. $^{\mathrm{z}}$

\begin{tabular}{lccl}
\hline & $\begin{array}{c}\text { Water-holding } \\
\text { capacity (\%) }\end{array}$ & $\begin{array}{c}\text { Air } \\
\text { space }(\%)\end{array}$ & $\begin{array}{c}\text { Total } \\
\text { porosity } \\
(\%)\end{array}$ \\
\hline Substrate & $15.50 \mathrm{ef}$ & $18.50 \mathrm{bc}$ & $34.00 \mathrm{~g}$ \\
Fafard & $43.46 \mathrm{~b}$ & $28.22 \mathrm{~b}$ & $71.69 \mathrm{a}$ \\
Perlite & $16.73 \mathrm{e}$ & $41.49 \mathrm{a}$ & $58.22 \mathrm{bcd}$ \\
Pumice & $19.86 \mathrm{de}$ & $28.5 \mathrm{~b}$ & $48.41 \mathrm{ef}$ \\
Turface & $26.59 \mathrm{~d}$ & $26.87 \mathrm{~b}$ & $53.46 \mathrm{cde}$ \\
Profile & $54.42 \mathrm{a}$ & $6.12 \mathrm{~d}$ & $60.54 \mathrm{bc}$ \\
Sand/Pro & $35.23 \mathrm{c}$ & $9.18 \mathrm{~cd}$ & $44.41 \mathrm{f}$ \\
Permatil & $9.59 \mathrm{f}$ & $42.78 \mathrm{a}$ & $52.37 \mathrm{de}$ \\
Axis & $38.23 \mathrm{bc}$ & $23.39 \mathrm{~b}$ & $61.69 \mathrm{~b}$ \\
\hline
\end{tabular}

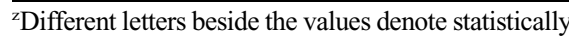
significant differences (Tukey's honestly significant difference). For all analyses of variance, the $P$ values for the model $\mathrm{F}$ ratio were $<0.0001$. particles greater than $2 \mathrm{~mm}$. There were many statistically significant differences in particle size distribution among the substrates (Table 5).

Regression models incorporating substrate physical properties explained most of the variation in growth parameters $\left(R^{2}\right.$ adj from 0.74 to 0.87 ; Table 6 ). In general, increased substrate water-holding capacity was associated with less growth as was increased percentage of coarse particles (sieve size \#5). The interaction between these also suppressed growth. Increased air space percentage increased growth as did increased percentage of fine particles (sieve size \#60). The interactions of these factors also had a positive effect on growth. Increased total porosity positively affected stem dry weight as did its interaction with percent coarse and moderately fine particle sizes. The substrate factors affecting stem dry weight were generally different from those affecting root, leaf, and total dry weight. For example, water-holding capacity did not significantly influence stem dry weight but did affect other growth factors and total porosity only affected stem dry weight, not other growth measures.

\section{Discussion}

The standard organic nursery substrate, Fafard, performed very well during this 18month study, better than nearly all of the inorganic substrates. However, one inorganic

Table 5. Particle size distribution for nine substrates used to grow Zamia pumila for 18 months. ${ }^{\mathrm{z}}$

\begin{tabular}{lccccr}
\hline Sieve size & $\# 5$ & $\# 10$ & $\# 35$ & $\# 60$ & $\# 120$ \\
\hline Hole diam $(\mathrm{mm})$ & 4 & 2 & 0.5 & 0.25 & 0.125 \\
Sand $(6 / 20)$ & $<0.01 \mathrm{~d}$ & $1.58 \mathrm{e}$ & $97.52 \mathrm{a}$ & $0.50 \mathrm{~d}$ & $0.10 \mathrm{~b}$ \\
Fafard & $2.46 \mathrm{c}$ & $21.34 \mathrm{~d}$ & $68.0 \mathrm{~b}$ & $5.73 \mathrm{~b}$ & $2.46 \mathrm{a}$ \\
Perlite & $6.42 \mathrm{~b}$ & $72.63 \mathrm{~b}$ & $20.95 \mathrm{e}$ & $<0.01 \mathrm{~d}$ & $<0.01 \mathrm{~b}$ \\
Pumice & $4.53 \mathrm{bc}$ & $85.04 \mathrm{a}$ & $8.55 \mathrm{f}$ & $1.07 \mathrm{~cd}$ & $<0.01 \mathrm{~b}$ \\
Turface & $<0.01 \mathrm{~d}$ & $67.42 \mathrm{~b}$ & $31.91 \mathrm{~d}$ & $<0.01 \mathrm{~d}$ & $<0.01 \mathrm{~b}$ \\
Profile & $<0.01 \mathrm{~d}$ & $<0.01 \mathrm{e}$ & $89.99 \mathrm{a}$ & $10.01 \mathrm{a}$ & $<0.01 \mathrm{~b}$ \\
Sand/Pro & $<0.01 \mathrm{~d}$ & $2.04 \mathrm{e}$ & $94.12 \mathrm{a}$ & $3.83 \mathrm{bc}$ & $0.10 \mathrm{~b}$ \\
Permatil & $98.32 \mathrm{a}$ & $1.69 \mathrm{e}$ & $0.22 \mathrm{f}$ & $<0.01 \mathrm{~d}$ & $<0.01 \mathrm{~b}$ \\
Axis & $<0.01 \mathrm{~d}$ & $49.61 \mathrm{c}$ & $47.76 \mathrm{c}$ & $1.13 \mathrm{~cd}$ & $<0.01 \mathrm{~b}$ \\
\hline
\end{tabular}

${ }^{\mathrm{z}}$ Values are percentages retained at each sieve size. Different letters beside the values denote statistically significant differences (Tukey's honestly significant difference). For all analyses of variance, the $P$ values for the model $\mathrm{F}$ ratio were $<0.0001$.

Table 6. Multiple regression model coefficients of effects of substrate physical properties on Zamia pumila growth. ${ }^{\mathrm{z}}$

\begin{tabular}{|c|c|c|c|c|}
\hline Physical property & $\begin{array}{l}\text { Logarithm } \\
\text { transformed } \\
\text { (root dry wt) }\end{array}$ & $\begin{array}{l}\text { Logarithm } \\
\text { transformed } \\
\text { (stem dry wt) }\end{array}$ & $\begin{array}{l}\text { Logarithm } \\
\text { transformed } \\
\text { (leaf dry wt) }\end{array}$ & $\begin{array}{c}\text { Logarithm } \\
\text { transformed } \\
\text { (total dry wt) }\end{array}$ \\
\hline WHC (\%) & -0.278 & & -0.749 & -0.581 \\
\hline Air space $(\%)$ & 0.0738 & 0.0865 & 0.203 & 0.151 \\
\hline $\mathrm{TP}(\%)$ & & 0.0203 & & \\
\hline Sieve size \#5 (\% retention) & -0.291 & -0.00989 & -0.911 & -0.677 \\
\hline Sieve size \#60 (\% retention) & 0.628 & 0.215 & 1.43 & 1.16 \\
\hline$(\mathrm{WHC}) \times(\# 5)$ & -0.0135 & & -0.0442 & -0.0324 \\
\hline$($ Air space $) \times(\# 60)$ & 0.0128 & 0.00223 & 0.0354 & 0.0259 \\
\hline$(\mathrm{TP}) \times(\# 5)$ & & 0.00826 & & \\
\hline \multirow[t]{2}{*}{$(\mathrm{TP}) \times(\# 60)$} & & 0.0104 & & \\
\hline & 0.799 & 0.744 & 0.872 & 0.819 \\
\hline
\end{tabular}

${ }^{\mathrm{z}}$ Models were developed by forward selection using the Akaike Information Criterion from the parameters of a model using all physical properties [water-holding capacity (WHC) (\%), air space (\%), total porosity (TP) (\%) sieve sizes $\# 5, \# 10, \# 35$, \#60, and \#120] and all possible two-way interactions. The factors listed are those that were selected for at least one model. Response variables were transformed to correct for nonhomogeneity of variances. substrate, coarse silica sand, outperformed Fafard and one other inorganic, perlite, performed nearly as well as Fafard, showing that a properly selected inorganic substrate can perform as well as a standard nursery substrate for growth of Zamia pumila.

The regression analyses suggest that higher percentages of coarse particles (\#5 sieve size) were associated with poorer growth, whereas higher percentages of fine particles (\#60 sieve size), especially when associated with higher airspace percentages, resulted in better growth (Table 6). This is because the coefficients for $\# 5$ sieve size were negative for all growth factors, whereas those for \#60 and air space were positive. The best performing substrates, sand (6/20 grade) and Fafard, also had $18 \%$ to $28 \%$ air space. This suggests that although Zamia pumila may need a minimum of $\approx 20 \%$ air space or more for best growth, this species may be sensitive to excessively large pores (perhaps larger than the finer roots of the plant) caused by very coarse substrates and benefits from also having more moderateto-fine particles to reduce average pore size. Ultimate roots of Zamia can have diameters of less than $1 \mathrm{~mm}$ (Fisher and Vovides, 2004) and larger proportions of very coarse particles over $4 \mathrm{~mm}$, which would likely create large pores, were detrimental to plant growth (Table 5). Such a phenomenon of sensitivity to excessively large pores has been observed in other plants (Passioura, 2002).

The majority of common symptoms of poor plant health in indoor plants are caused by overwatering and poor drainage (Taylor et al., 2010). Zamia plants have been observed to grow best in well-drained substrates (Culbert, 2010; Whitelock, 2002). A combination of lower water-holding capacity, high air-filled space, and particle size heterogeneity (which likely results in infilling of larger pores with smaller particles) of perlite and pumice likely contributed to better growth in these substrates (Table 4). By contrast, the narrow range of mostly large particle sizes in Turface may lead to larger average pore size. The particles of sand have little surface area per unit of volume compared with clay, which has internal water and nutrient storage. However, coarse sand provides excellent gas exchange and physical support for the plant (Nelson, 2003), and the narrow particle size distribution of the grade used in this study, concentrated around the \#35 sieve size, is clearly suitable for Zamia growth. Particle size distribution for sand (6/20 grade) and Permatil will not change appreciably over time as a result of their hardness and stability. However, the particle size distribution of the other substrates could change as a result of weathering.

On visual inspection, most of the inorganic substrates provided a fairly uniform distribution of moisture in the soil. By contrast, Turface tends to dry out at the top of the pot and remain wetter at the bottom. Therefore, Turface must be monitored closely to avoid water stress (Sard, 1989). Water release curves for inorganic amendments added to the root zone were studied for calcined clay, calcined diatomaceous earth, calcined 
volcanic ash, and zeolite (Curtis, 2008). These authors found that the inorganic amendments did not release appreciable amounts of internally held water until exposed to matric potentials more negative than usual for turfgrass management. Thus, some inorganic substrates should be kept wetter than organic substrates to ensure adequate moisture availability to plant roots. This also shows that irrigation frequency potentially affected the results because of differences in drainage and matric potential.

Although plants grown in Fafard grew well for 18 months, the breakdown of standard organic substrates would eventually lead to poor drainage that can contribute to problems with root health and foliar deterioration (Taylor et al., 2010), whereas coarse silica sand would not break down. Typical container substrates are $75 \%$ or more organic matter and breakdown of the substrates typically leads to a deficient level of $\mathrm{O}_{2}$ and an excess of $\mathrm{CO}_{2}$ in the root zone, especially when plants are saturated with water (Whitcomb, 2003). Because cycads often have a growing cycle of many years in the nursery, organic substrates may not be the best choice.

Choice of substrate greatly influences growth of Zamia pumila and substrates should be chosen with great care to ensure the best plant growth and health. Coarse silica sand (6/20 grade) is an excellent growing substrate for Zamia pumila, outperforming a standard commercial nursery mix and a wide range of alternative inorganic substrates. These results are likely applicable to a wide range of Zamia, because both a Caribbean taxon from a dry forest habitat and southern Central American taxa from rainforest habitats grew well in inorganic substrates in a previous study (Calonje et al., 2010). Thus, coarse silica sand should be an excellent general purpose substrate for growth of Zamia.

\section{Literature Cited}

Bilderback, T.E., S. Warren, J. Owen, and J. Albano. 2005. Healthy substrates need physicals too. HortTechnology 15:747-751.

Calonje, C., C. Husby, and M. Calonje. 2010. Germination and early seedling growth of rare Zamia spp. in organic and inorganic substrates: Advancing ex situ conservation horticulture. HortScience 45:679-683.

Calonje, M., J. Kay, and M.P. Griffith. 2011 Propagation of cycad collections from seed: Applied reproductive biology for conservation. Sibbaldia 9:77-96.

Calonje, M., L. Stanberg, and D. Stevenson. 2013. World list of cycads: A comprehensive taxonomic reference. 12 July 2013. <http://cycadlist. org/>.

Chavez, V.M. and R.E. Litz. 2007. Recovery and difficult to regenerate species: The cycad example. Acta Hort. 738:51-61.

Culbert, D.F. 2010. Florida coonties and Atala butterflies. ENH 117. Institute of Food and Agricultural Sciences, University of Florida, Davie, FL.

Curtis, M.J. 2008. An alternate method for measuring plant available water in inorganic amendments. Crop Sci. 48:2447-2452.

Dehgan, B. 1999. Propagation and culture of cycads: A practical approach. Acta Hort. 486: 123-131.

Donaldson, J.S., B. Dehgan, A.P. Vovides, and W. Tang. 2003. Cycads in the trade and sustainable use of cycad populations, p. 39-47. In: Donaldson, J.S. (ed.). Cycads: Status survey and action plan. IUCN, Gland, Switzerland.

Fisher, J.B. and A.P. Vovides. 2004. Mycorrhizae are present in cycad roots. Bot. Rev. 70:16-23.

Griffith, M.P., C.E. Husby, and M. Calonje. 2010. Cycad collections in the modern context: Challenges, opportunities, investments, and outcomes. Proc. 4th Global Bot. Congr. p. 1-10.

IUCN Red List of Threatened Species. 2010. International Union for Conservation of
Nature. 1 Oct. 2012. <http://cmsdata.iucn.org/ downloads/cycad/factsheet/final.pdf>.

Kang, J.Y., H.-H. Lee, and K.-H. Kim. 2004. Physical and chemical properties of inorganic substrates used in Korea. Acta Hort. 644:237242.

Kay, J., A. Strader, V. Murphy, L. Nghiem-Phu, M. Calonje, and M.P. Griffith. 2011. Palma Corcho: A case study in botanic garden conservation horticulture and economics. HortTechnology 21:474-481.

Michel, J.C. 2009. Influence of clay addition on physical properties and wettability of peat growing substrates. HortScience 44:16941697.

Nelson, P. 2003. Root substrate, p. 198. Greenhouse operations and management. 6th ed. Prentice Hall, Upper Saddle River, NJ.

Osborne, R., M.A. Calonje, K.D. Hill, L. Stanberg, and D.W. Stevenson. 2012. The world list of cycads. In: Proc. 8th Intl. Conf. on Cycad Biology (CYCAD 2008), Jan. 2008, Panama City, Panama. Mem. N. Y. Bot. Gard. 106:480510.

Passioura, J.B. 2002. Soil conditions and plant growth. Plant Cell Environ. 25:311-318.

Rischer, H. 2000. Growing Nepenthes in a completely inorganic substrate. Intl. Carnivorous Plant Soc. Nwsl. Carnivorous Plant News 29: $50-53$.

Sard, E.L. 1989. An experiment with Turface. J. Bromeliad Soc. 39:274-275.

Tang, W. 1990. A guide to pollinating and collecting seeds of cycads. The Cycad Manual 13-16.

Taylor, N.J., S. Nameth, and J. Chatfield. 2010. Diagnosing problems on indoor plants. HYG3068-96. 1 Oct. 2012. <http://ohio.osu.edu/ hyg-fact/3000/3068.html>.

Walters, T.W. 1999. Off-site cycad conservation: What is off-site preservation? Cycad Nwsl. 22:110-112.

Whitcomb, C.E. 2003. Plant production in containers II. Lacebark, Inc., Stillwater, OK.

Whitelock, L.M. 2002. The cycads. Timber Press, Portland, OR.

Zanoni, T.A. 1982. Guayiga (Zamia) in Hispaniola. Cycad Nwsl. 111:5-13. 